\title{
Thiazolidinone motif in anticancer drug discovery. Experience of DH LNMU medicinal chemistry scientific group
}

\author{
R. B. Lesyk, B. S. Zimenkovsky, D. V. Kaminskyy, A. P. Kryshchyshyn, \\ D. Ya. Havryluk, D. V. Atamanyuk, I. Yu. Subtel'na, D. V. Khyluk
}

Department of Pharmaceutical, Organic and Bioorganic Chemistry, Danylo Halytsky Lviv National Medical University 69, Pekarska St., Lviv, Ukraine, 79010

dr_r_lesyk@org.lviv.net; dankaminskyy@gmail.com

\begin{abstract}
The aim was analysis of 4-thiazolidinones and related heterocyclic systems anticancer activity data and formation of some rational design directions of potential anticancer agents. Synthetic research carried out in Danylo Halytsky Lviv National Medical University (DH LNMU) allowed us to propose a whole number of new molecular design directions of biological active 4-thiazolidinones and related heterocyclic systems, as well as obtain directed library that numbers over 5000 of novel compounds. At the present time in vitro anticancer activity screening was carried out for more than 1000 compounds (US NCI protocol (Developmental Therapeutic Program), among them 167 compounds showed high antitumor activity level. For the purpose of optimization and rational design of highly active molecules with optimal «drug-like» characteristics and discovering of possible mechanism of action SAR, QSAR analysis and molecular docking were carried out. The ultimate aim of the project is creating of innovative synthetic drug with special mechanism of action and sufficient pharmacological and toxicological features. Some aspects of structure-activity relationships were determined and structure design directions were proposed. The series of active compounds with high anticancer activity and/or selectivity levels were selected.
\end{abstract}

Key words: synthesis, 4-thia(imida)zolidinones, thiopyrano[2,3-d] thiazoles, anticancer activity, (Q)SAR.

Introduction. Thiazolidinone derivatives are well known class of biological active substances [1-3] that became basic for the whole number of innovative medicinal agents, such as hypoglycemic thiazolidinediones (Pioglitazone and its analogues) [4], aldose reductase inhibitors (Epalrestat) [5], dual inhibitors of COX-2/5-LOX (Darbufelon) [6], modern diuretics (Etozoline) [7], Mur family inhibitors (UDP-MurNAc/ L-Ala ligases) etc. [8]. Recently thiazolidinone research area unexpectedly became interesting and promising for oncology. In-depth study of PPARs allowed to put forward and validate the concept of anticancer potential existence of PPAR agonists including thiazoli-

(c) Institute of Molecular Biology and Genetics NAS of Ukraine, 2011 dinediones $[9,10]$. In addition, inhibitors of antiapoptotic proteins $\mathrm{Bcl}-\mathrm{X}_{\mathrm{L}}$ and $\mathrm{BH} 3$ [11] which contribute to modulation of programmed cell death (apoptosis), as well as inhibitors of tumor necrosis factor TNF $\alpha$ [12], necroptosis inhibitors [13], integrin antagonists [14], inhibitors of JSP-1 [15], Pim-2 and Pim-1 protein kinases [16], COX-2 [17] etc. were identified among 4-thiazolidinones.

Biological active thiazolidinones and related heterocycles refer to one of the most successful scientific projects in the area of pharmacy of DH LNMU (Fig. 1). It is based on three strategic vectors: a) organic synthesis; b) pharmacological research; c) rational design of «drug-like» molecules (virtual screening: QSARanalysis, molecular docking etc.) $[1,18]$. 


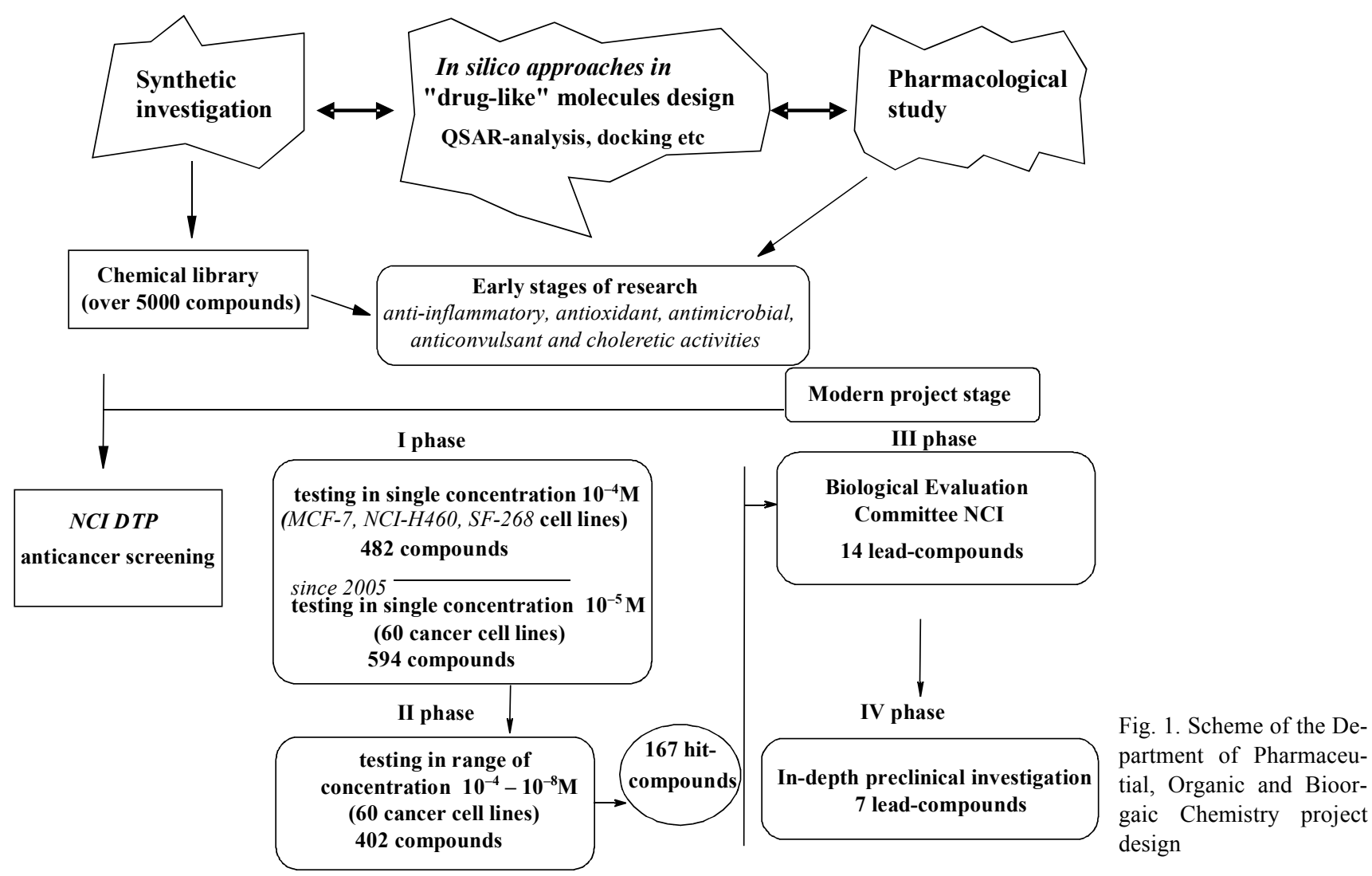

In the starting stages of the project anti-inflammatory [19-21], antimicrobial [22, 23], anticonvulsant, choleretic [24] and antioxidant [25] activities were identified. In spite of the series of perspective results, progress of the project brings to some research directions changes, notably it has focused on the search of new anticancer agents. Taking into account global processes in the world science and the necessity of planning the tactics of narrowly defined groups development in competition environment of the biological active molecules market, screening research are carried out within the National Cancer Institute (NCI) of National Institute of Health (NIH) scientific programs (Developmental Therapeutic Program, Bethezda, USA, http:/dtp.nci.nih.gov) [26-30]. The ultimate aim of the project is creating of innovative synthetic drug with special mechanism of action and sufficient pharmacological and toxicological features.

Results and discussion. Synthetic research in the area of 4-thiazolidinones derivatives. Synthetic strategy consists in structure modification of azolidinone ring formed in different [2+3]-cyclocondensation re- actions and modifying it in the positions 2, 3, 4 and 5 . Six key types of the reactions were generally used (Knoevenagel reaction, [2+3]-cyclocondensation, $\mathrm{N}$ alkylation, acylation, heterodiene synthesis, «domino» reactions) that allowed to obtain directed library with over 5000 new thiazolidinones and related heterocyclic systems (Fig. 2) [1, 21, 23, 31-40].

While applying the research strategy through the past few years we succeeded in gaining a number of interesting synthetic results that make possible to extend the field of the chemistry of thiazolidinone and related heterocycles, especially in the scope of «drug-like» molecules design.

Anticancer activity evaluation of 4-thiazolidinones and related heterocyclic systems and efficient approaches to interpretation of «structure-activity» correlation. Obtained real library of heterocyclic compounds became an object for study concerning anticancer activity identifying according to the standard NCI procedure. On the first stage high-performance in vitro prescreening was held on 3 tumor cell lines (NCIH460, MCF-7 and SF-268) in concentration $10^{-4} \mathrm{M}$. 


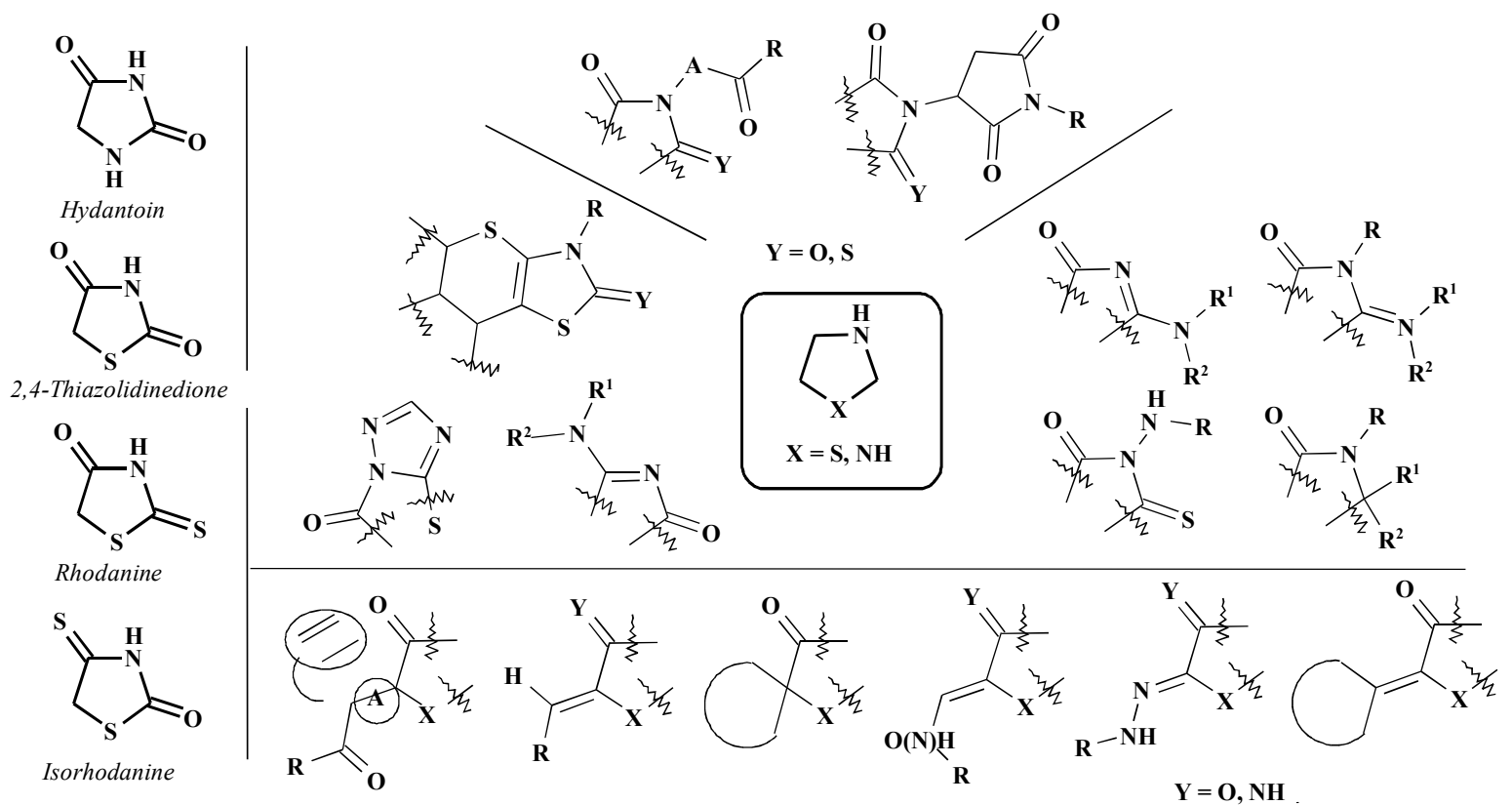

Fig. 2. Structure of compounds sub-libraries, synthesized at the Department of Pharmaceutical, Organic and Bioorganic Chemistry

Since 2005 the prescreening criteria became strict and the procedure of prescreening consists in testing of compounds activity on 60 tumor cell lines in concentration $10^{-5} \mathrm{M}$. On the second stage of prescreening active compounds are tested in vitro at 10 -fold dilutions of five concentrations $\left(10^{-4}-10^{-8} \mathrm{M}\right)$ on 60 tumor cell lines including lines of leukemia, non-small sell lung cancer, colon cancer, CNS cancer, melanoma, ovarian cancer, prostate cancer and breast cancer. In this assay three dose-response parameters are obtained: 1) growth inhibition of $50 \%-\mathrm{GI}_{50} ; 2$ ) total growth inhibition - TGI; 3$) \mathrm{LC}_{50}$. Whereas the $\mathrm{GI}_{50}$ may be viewed as a growth-inhibitory level of effect, the TGI signifies a «total growth inhibition» or cytostatic level of effect. The $\mathrm{LC}_{50}$ is the lethal concentration, «net cell killing» or cytotoxity parameter. If the tested parameters $\left(\mathrm{pGI}_{50}, \mathrm{pTGI}\right.$ and $\left.\mathrm{pLC}_{50}\right)$ specified in negative $\log 10$ units are less then $<4.00$ these compounds are assigned as active.

Now among 1076 tested compounds 402 (37.4\%) have successfully passed prescreening phase (Fig. 1). After passing the second testing phase 14 compounds were submitted for consideration of NCI Biological Committee, among them 7 compounds are affirmed for the in-depth in vivo preclinical trials as potential anticancer agents. Tested compounds introduce all the sublibraries (Fig. 2) of obtained derivatives and accor- ding to the data of NCI specialists most of the highly active compounds don't belong to any class of known anticancer agents that is weighty argument for their indepth investigation.

When analyzing the in-depth in vitro research results [18] it is worth to mention that in the anticancer selectivity rating the most sensitive to 4-thiazolidinones and related heterocyclic systems was the line of leukemia. Level of selectivity on the cell lines of nonsmall sell lung cancer, CNS cancer and breast cancer are approximately the same. Series of cell lines, such as leukemia lines (CCRF-CEM, HL-60(TB), RPMI8226, SR, K-562, MOLT-4), CNS cancer line (U251), non-small cell lung cancer line (HOP-92), renal cancer cell lines (UO-31, 786-O), colon cancer line (HCT116) as well as breast cancer line (MDA-MB 231) have been found to be the most sensitive to testing compounds. The ranking is given in decreasing order of high antitumor effect frequency for tested compounds. Thus based on the obtained results the hypotheses of specific anti-leukemia activity of heterocycles containing «thiazolidinone matrix» may be put forward.

Obtained results allowed to form a number of structure-anticancer activity relations and outline the rational design directions. SAR analysis was carried out within each of the presented sub-libraries of azolidinone derivatives (Fig. 3-5). 

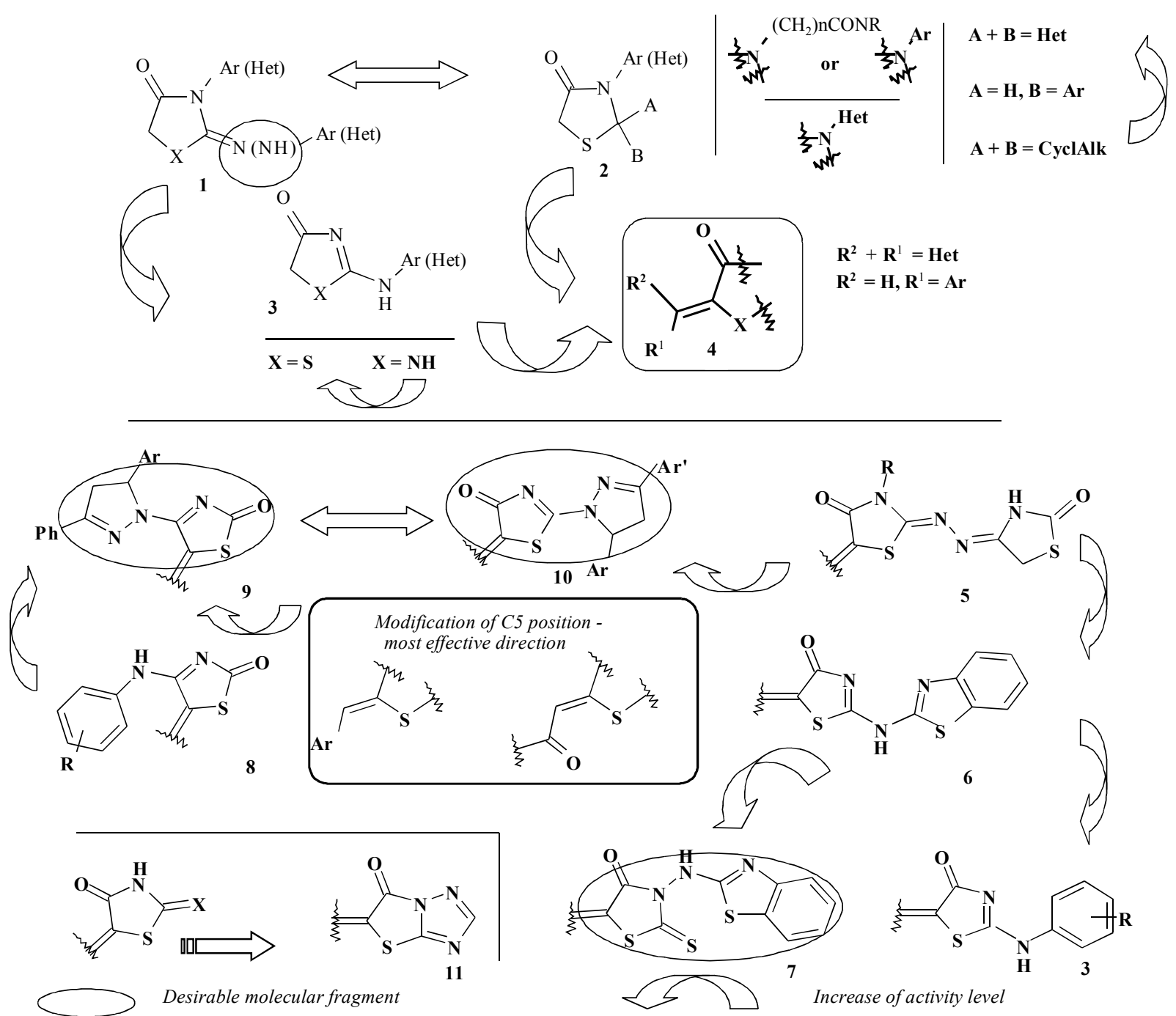

Fig. 3. Some features of structure-anticancer activity relationships in synthesized 2,3-disubstituted-4-thiazolidinones and heterylsubstituted thiazolidinones sub-libraries

Anticancer effect realization of 2-substituted 4thiazolidinones $(\mathbf{1}, \mathbf{2})$ (Fig. 3) depends on the nature of substituents in the positions $\mathrm{C} 2$ and $\mathrm{N} 3$, moreover relation between activity levels of the derivatives $\mathbf{2}$ and $\mathbf{3}$ wasn't established. Retrospective analysis of these compounds showed that anticancer activity increases while transition from cycloalkyl moiety to heteryl moiety in position $\mathrm{C} 2$ and the moieties of amino acid or aromatic amine are eligible in position N3. Instead of this compounds of row 1 with the 2-imino fragment are characterized by the higher activity, while presence of substituent in the position N3 is not always desirable (3). Imidazolidinone isosters $(\mathrm{X}=\mathrm{NH})$ of sub-libraries $\mathbf{1}, \mathbf{3}$ posses lower activity level than compounds based on thiazolidinone $(X=\mathrm{S})$ [39]. Suggested and confirmed by us hypotheses about the crucial role of the presence and the nature of the substituent in the position C5 in anticancer effects realization $[1,36]$ is absolutely confirmed in the case of 2-substituted 4-thiazolidone derivatives 4 . In this number of heterocycles the compounds with aryl(heteryl)idene fragments are characterized by the maximum level of anticancer activity.

One of the effective and frequently used directions of new biological active substances research in modern medical chemistry is the direction based on the pharmacophore hybrid approach usage [41]. This approach 
provides combination of different pharmacophore cycles with equal biological activity and affinity to different biotargets in one molecule. Such combination often allows to reach the potantiation of action (synergic effect). The results of our research work confirm this hypothesis and help us to identify high antitumor effect of heteryl substituted 2(4)-thiazolidinones.

Study of the «structure-anticancer activity» relationship makes possible to establish that antimitotic effect displaying depends on the nature of heterocyclic fragment. Moving from non-condensed bis-thiazolidinones 5 to 2-pyrazolin substituted $\mathbf{1 0}$ and 2-benzthiazolamine-4-thiazolidinones $\mathbf{6}$ is characterized by the increasing of activity $[35,38]$. It is worth to mention that position of heterocyclic fragment relative to the basic (thiazolidinone) cycle has ambiguous influence on the activity appearance. In the row of non-condensed systems with thiazolidinone and benzthiazole fragments moderate activity intension is traced when changing the position of benzthiazole cycle from $\mathrm{C} 2(\mathbf{6})$ to N3 (7), while changing the position of pyrazoline cycle from C2 (10) to C4 (9) doesn't influence the antimitotic effect realization [37]. It is established that 4-pyrazoline substituted 2-thiazolidones 9 are more active than 4-arylamine-2-thiazolidinones $\mathbf{8}$, at the same time 2arylamine-4-thiazolidinones isomers 3 possess higher or equal activity than 2-heteryl substituted derivatives $\mathbf{6 , 1 0}$. In general, structure of the substituent in position $\mathrm{C} 5$ of thiazolidinone cycle is determinative for the anticancer activity realization for all the heteryl substituted thiazolidinones. That's why modification of mentioned position is the key concept of directed synthesis of novel anticancer agents in described class of compounds. When moving from thiazolidinone scaffold to condensed thiazolo[3,2-b][1,2,4]triazol-6-one system light activity increasing occurs [32], though C5-substituent remains the determining factor.

The group of 4-thiazolidinone-3(5)-alkanecarboxylic acids is one of the most studied groups of thiazolidinone derivatives with the determined molecular mechanism of biological activity realization, including anticancer activity [42]. Comparison of anticancer activity of 4-thia(imida)zolidinone-5-carboxylic acids (12) and 4-thia(imida)zolidinone-3-carboxylic acids (13) indicates that the latter show higher antitumor activity level (Fig. 4). In the series of presented derivatives the- re is no significant difference between the levels of antitumor activity of thiazolidinone $(\mathrm{X}=\mathrm{O})$ and rhodanine $(X=S)$ derivatives. However, the substitution of a sulfur atom in thiazolidinone cycle for the atom of nitrogen (transition from 2,4-thiazolidinediones to 2,4imidazolidinediones) in compounds $\mathbf{1 3}$ contributes to the intensification of anticancer activity and appearance of selectivity of 4-imidazolidinone-3-carboxylic acids effects. Thus for the hydantoin-3-acetic acids the significant effect on the leukemia lines was observed, though there was almost no influence on the other cancer cell lines [36]. This fact allows to consider 5-arylidene-2,4-imidazolidinedione-3-acetic acids amides as «hit-structures» for the anti-leukemia agents search. Simultaneous presence of substituents in the positions $\mathrm{C} 5$ and $\mathrm{N} 3$ of the basic heterocycle is desirable and is proved by the higher anticancer activity level of 4-thiazolidinone-3,5-alkanecarboxylic acids $(\mathbf{1 4}, \mathbf{1 5})$ and 5arylidene-4-thiazolidinone-3-alkanecarboxylic acids (16) [43]. Comparison of the activity of the compounds 14-16 points an advantage of ylidene moiety, namely the aryl(heteryl)idene fragment. Also, it is found that amides are more active than esters and free acids irrespective of the presented acids series they belong to. Antitumor activity evaluation of 5-ylidenerhodanine-3-succinic acids (17) proved presented relation and allowed us to make a suggestion that 3-(4-oxo-2-thioxothiazolidine-3-yl)-pyrrolidine-2,5-dione fragment is probable pharmacophore for this series of compounds [44]. The position C-5 of rhodanine cycle and nitrogen atom of pyrrolidine cycle are considered to be the main directions of its chemical modification. Utilization of thiazolidinone-alkanecarboxylic acids for the structure optimization of other scaffolds is effective approach in novel antitumor agents design; it is elucidated by the example of triterpenoid structure modification (18) and may be taken as the variant of hybrid pharmacophore approach.

Annealing of heterocyclic fragments as widespread method used for conformational flexibility limitation, is perspective and not sufficiently studied direction of biological active substances search. Possibility of fused thiazole heterocyclic systems 20 (Fig. 5) to imitate some biophore fragments of their synthetic precursors, namely 5-ylidene-4-thiazolidinones $\mathbf{1 9}$, allowed us to put forward the hypothesis about activity remaining in 


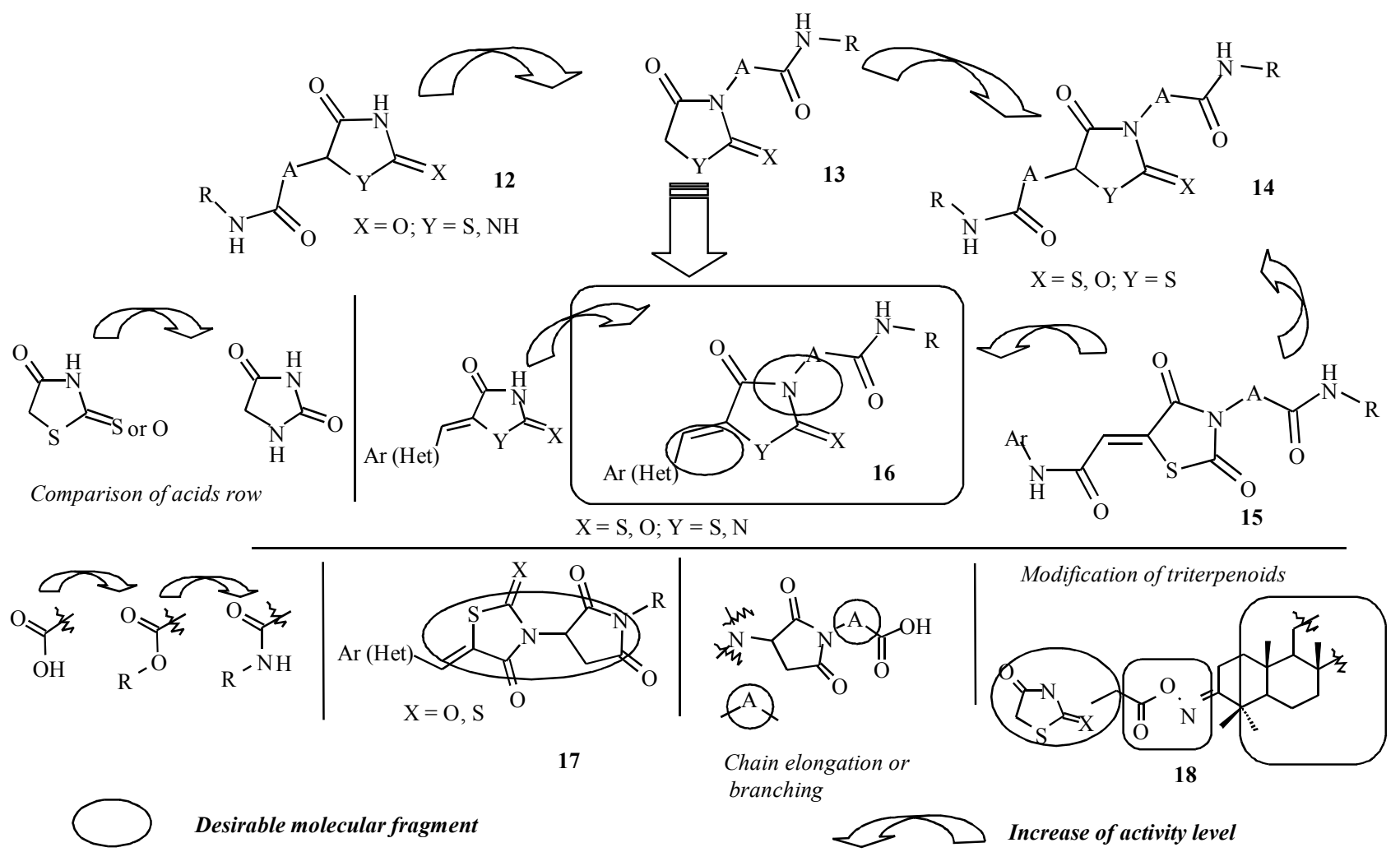

Fig. 4. Some features of structure-anticancer activity relationships in sub-library of synthesized azolidinone-carboxylic acids derivatives

their condensed derivatives $[31,34]$. Based on antitumor activity retrospective analysis we established that activity level, mainly, depends on the surroundings of thiopyrane fragment. Basing on the comparison of thiopyrano[2,3-d]thiazoles derivatives activity we can't determine precise structure-activity relationship. Though it should be noted that antitumor effect increases when moving from isothiochromeno[4a,4-d] $[1,3]$ thiazole derivatives (21) to chromeno[ $\left.4^{\prime}, 3^{\prime}: 4,5\right]$ thiopyrano[2,3-d]thiazoles (22), the same tendency is observed in the series 23-25 and 26-28. The optimal surroundings of thiopyrane fragment in thiopyrano [2,3-d]thiazole-2-ones is naphtoquinone moiety (25) or unsubstituted norbornane fragment (28). In all series of mentioned derivatives isorhodanine isosters $(\mathrm{X}=\mathrm{O})$ are more active than thiorhodanine derivatives $(X=S)$ and the main direction of highly active anticancer agents rational design is introduction of the substituent in position N3. Realization of this method presented by the example of chromeno[4',3':4,5]thiopyrano[2,3-d] thiazoles (22) [45, 46] allows achieving significant increasing of the level and/or selectivity of studied substances anticancer activity in comparison with $\mathrm{N}$-unsubstituted analogues, moreover presence of $\mathrm{N}$-arylacetamide fragments is desirable. The optimal molecular fragments that cause increasing of the activity level of thiopyrano[2,3-d]thiazole-2-ones and fragments are presented at the Fig. 5 .

The Fig. 6 presents «hit-compounds» from different groups that possess high antimitotic effect in vitro in submicromolar concentrations $\left(10^{-5}-10^{-7} \mathrm{M}\right)$ and are characterized by the low in vivo toxicity level.

In silico method of anticancer activity data analysis. The COMPARE analysis was performed for the active compounds in order to investigate the similarity of their cytotoxicity pattern (mean graph fingerprints) with those of known anticancer standard agents, NCI active synthetic compounds and natural extracts, which are present in public available databases. Such in silico analysis consists in the comparison of the patterns of 

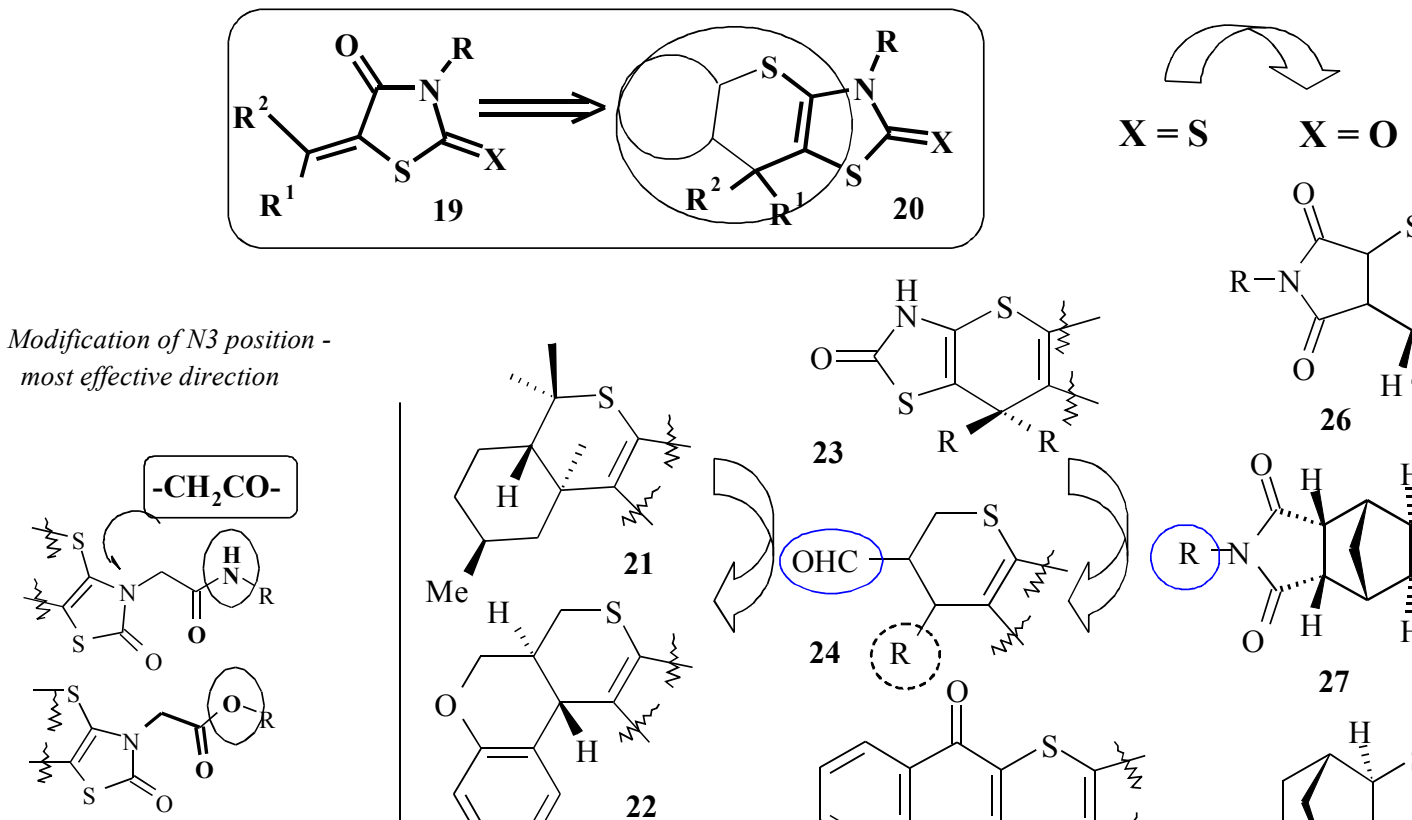

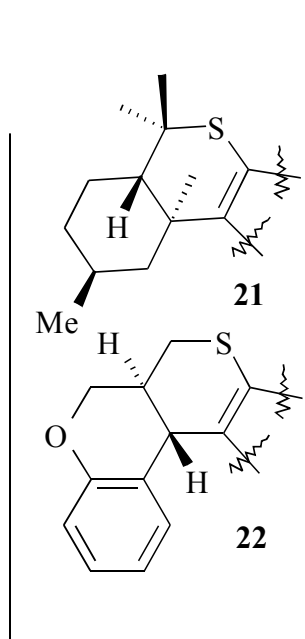

Hal- Aryl, Het
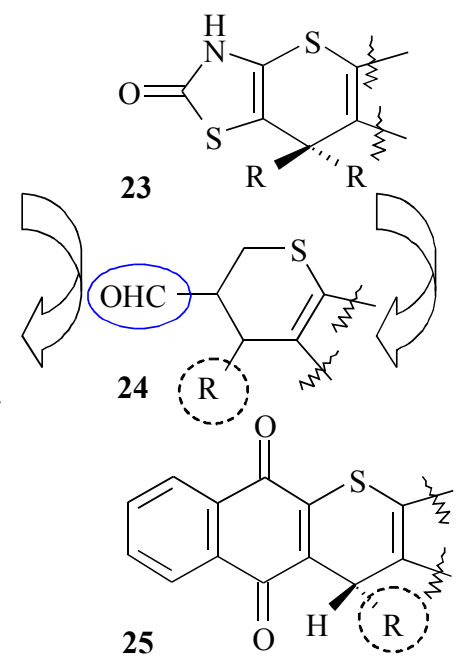

Direction of chemical modification

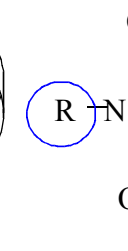

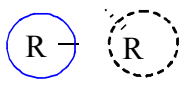

Fig. 5. Some features of structure-anticancer activity relationships in sub-library of synthesized thiopyrano[2.3-d]thiazole derivatives

differential growth inhibition for cultured cell lines and can potentially gain insight into the mechanism of the cytotoxic action. It is accessible for the practical usage on the web portal of NCI (USA, http://dtp.nci.nih.gov/ docs/compare/compare.html) $[47,48]$ and may indirectly indicates possible mechanism of cytotoxic action. If the data pattern correlates well with that of compounds belonging to a standard agent database (Pearson's correlation coefficient (PCC) $>0.6$ ), the compound of interest may have the same mechanism of action. On the other hand, if the activity pattern does not correlate with any standard agent, it is possible that the compound has a novel/another mechanism of action. Standard COMPARE analysis was performed at the $\mathrm{GI}_{50}$ and TGI levels.

For synthesized heterocyclic substances was established correlation with the inhibitors of tubulin polymerization, RNA polymerase, $p$-glycoprotein or topoisomerase II, inductors of apoptosis, activators of caspases, that allow prediction of mentioned mechanism of anticancer action for 4-thiazolidinone derivatives and related heterocyclic systems. It is worth to mention interesting fact of significant values of correlation coefficients of thiazolidinone derivatives from different sub-libraries $[35,39]$ to the S-trityl-L-cysteine (NSC $83265, r=0.702$ ), aminoacyl-tRNA synthetases inhibitor with antiproliferative effect against leukemia [49].

In silico methods, such as molecular docking and QSAR-analysis are widely used in our research work for rational design of potential anticancer agents. Currently for highly active substances from different groups is performed flexible molecular docking (using Glide and Fred programs) to «classical» for 4-thiazolidinones biotargets, such as PPAR $\gamma$ (codes 1FM6 and $1 \mathrm{NYX}$ ), protein complex Bcl- $\mathrm{X}_{\mathrm{L}}-\mathrm{BH} 3$ (1BXL) and tubulin (1SA1). We chose tubulin because of high values of Pearson's correlation coefficient of synthesized compounds and classical tubulin polymerization inhibitors. QSAR-analysis of antitumor activity parameter $\operatorname{lgGI}{ }_{50}$ with the usage of docking scoring functions and molecular descriptors $\left(\mathrm{M}_{r}, \operatorname{lgP}\right.$, TPSA, HOMO and LUMO, $\mu, q_{\min ,}$ and $\left.q_{\max }\right)$ allowed obtaining series of re- 


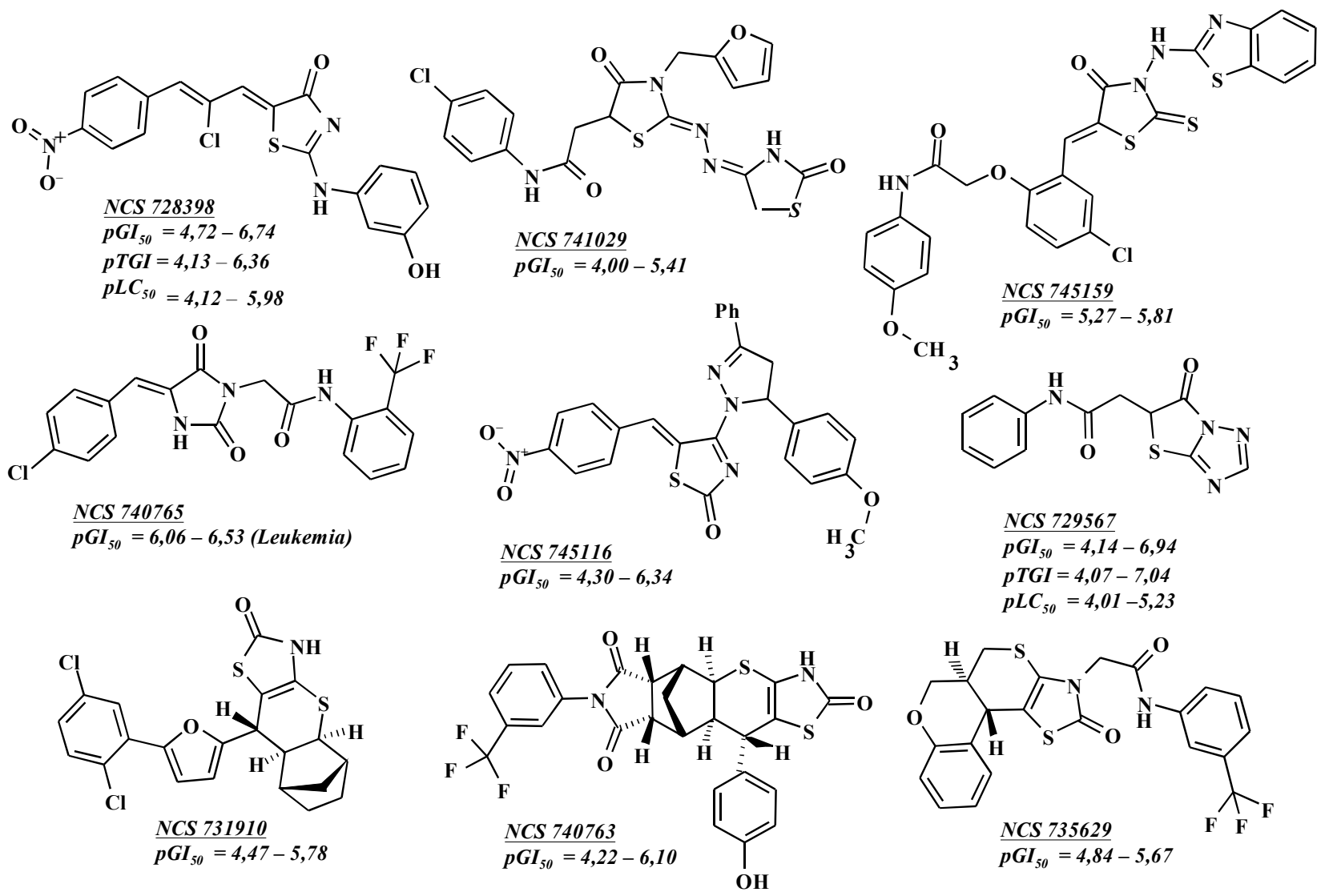

Fig. 6. Structures of some synthesized hit-compounds with high in vitro antitumor level

liable QSAR models. So, in the case of thiopyrano[2, 3d]thiazole-2-ones, models 1-4 indicate the highest correlation of $\operatorname{lgGI}{ }_{50}$ parameter for leukemnia, prostate and CNS cancer cell lines with LUMO (energy of the lowest unoccupied molecular orbital) and scoring functions values to tubulin molecules and protein complex $\mathrm{Bcl}-\mathrm{X}_{\mathrm{L}}-\mathrm{BH} 3$ which may be used as potential targets for the anticancer agents design and virtual screening [31]:

$\operatorname{lgGI}_{50}($ Breast Cancer $/ \mathrm{T}-47 \mathrm{D})=34.787 \cdot \mathrm{LUMO}+0.002 \cdot \mathrm{ZB}$ (tubuline)

$N=11 ; r^{2}=0.91 ; S=0.13 ; F=43 ; q^{2}=0.82 ;$

$\operatorname{lgGI}_{50}($ Breast Cancer/T-47D) $=35.259 \cdot \mathrm{LUMO}-0.015 \cdot \mathrm{PLP}$

$(1 \mathrm{BLX})-0.029 \cdot \mathrm{CS}(1 \mathrm{BLX})$

$N=11 ; r^{2}=0.93 ; S=0.11 ; F=33 ; q^{2}=0.88$;

$\operatorname{lgGI}{ }_{50}\left(\right.$ Colon Cancer/HCT-116) $=0.611 \cdot \mu-2.294 \cdot q_{\min }+$ $+0.046 \cdot \mathrm{CS}(1 \mathrm{FM} 6)$

$N=10 ; r^{2}=0.93 ; S=0.07 ; F=32 ; q^{2}=0.81 ;$

$\operatorname{lgGI}_{50}(\mathrm{CNS}$ Cancer $/ \mathrm{SNB}-19)=-0.388 \cdot \lg \mathrm{P}-5.008 \cdot q_{\min }-$ $-0.035 \cdot$ PLP $(1 \mathrm{BLX})$

$N=11 ; r^{2}=0.91 ; S=0.09 ; F=24 ; q^{2}=0.81$.
Series of valid QSAR models 5-8 were calculated for 5-ylidene-2-thioxo-4-oxothiazolidinone-3-succinic acids derivatives [44]:

$\operatorname{lgGI}_{50}$ (Lung Cancer $\left./ \mathrm{NCI}-\mathrm{H} 322 \mathrm{M}\right)=-0,507 \cdot \lg \mathrm{P}-18.598 \times$ $\times$ LUMO $-0,046 \cdot \mathrm{ZB}(1 \mathrm{FM} 6)$

$N=10 ; r^{2}=0.96 ; S=0.05 ; F=48 ; q^{2}=0.91$;

$\operatorname{lgGI}_{50}$ (Lung Cancer/HOP-92) $=-0,636 \cdot q_{\max }+0,006 \cdot \mathrm{ZB}$ (1SA1)

$N=13 ; r^{2}=0.95 ; S=0.20 ; F=95 ; q^{2}=0.91$;

$\operatorname{lgGI}_{50}($ Lung Cancer/A549/ATCC) $=-0,003 \cdot \mathrm{MW}+0.012 \times$ $\times$ TPSA $+0,052 \cdot \mathrm{ZB}(1 \mathrm{BXL})$

$N=13 ; r^{2}=0.93 ; S=0.09 ; F=40 ; q^{2}=0.86$;

$\operatorname{lgGI}{ }_{50}\left(\right.$ Ovarian Cancer $/ \mathrm{MD} \_$mean $)=-0,185 \cdot \lg \mathrm{P}+0,064 \times$ $\times \mathrm{ZB}(1 \mathrm{BXL})-0,004 \cdot \mathrm{SG}(1 \mathrm{BXL})$

$N=13 ; r^{2}=0.93 ; S=0,07 ; F=40 ; q^{2}=0,86$.

Docking functions comparison in the model range 5-8 shows that the best is correlation of Zapbind functions values (Fred) and E-model (Glide). In determined models values of $\operatorname{lgP}$, LUMO, HOMO and docking 
ratings to $\mathrm{Bcl}-\mathrm{X}_{\mathrm{L}}-\mathrm{BH} 3$ protein complex, $\mathrm{PPAR} \gamma$, as well as to tubulin protein predominate. However, it should be noted that if there is docking function for $\mathrm{Bcl}-\mathrm{X}_{\mathrm{L}}-\mathrm{BH} 3$ protein complex in the model, its partial contribution in the PLS model is more essential, than if docking is performed to other biotargets. In consequence of performed studies in silico it can be assumed that the most probable mechanism of anticancer activity of 5-ylidene-4-thiazolidinone-3-succinic acids may be binding with the anti-apoptotic protein complex Bcl- $\mathrm{X}_{\mathrm{L}}-\mathrm{BH} 3$.

Thus, based on the complex use of molecular docking, COMPARE analysis and QSAR analysis we put forward a hypothesis about probable 4-thiazolidinones and related heterocycles influence on the apoptotic bisystem. Currently we continue with complex studies using molecular biology methods to confirm our hypothesis.

Project outline. The ultimate aim of scientific project of the DH LNMU department of pharmaceutical, organic and bioorganic chemistry is creating of drug prototype with unique mechanism of action for the indepth preclinical and clinical trials. So, besides going on with synthetic and pharmacological studies such tasks are privileged for our group:

optimization of «hit-compounds» biopharmaceutical characteristics;

«hit-compounds» improvement using rational design methods;

experimental confirmation and identification of biotargets to anticancer 4-thiazolidinones and related heterocyclic systems;

usage of modern delivery systems (drug delivery system) for the drug candidates as actual approach in drug technology and biopharmacy.

Conclusions. Novel methods for sulfur- and nitrogen containing heterocycles synthesis are worked out that allow to obtain over 5000 of new substances for pharmacological screening, as well as broaden out the field of thiazolidinone and related heterocycles studying in the context of original «drug-like» molecules design.

Based on systematic combination of pharmacological screening methods and in silico data the anticancer activity is determined as privileged for thiazolidinones and related heterocyclic systems that allowed identification of «hit-compounds» series.
Some aspects of structure-activity relationships were determined and structure rational design directions were proposed. Among tested compounds 167 samples showed high antitumor activity level and their in-depth preclinical studies are in progress.

Acknowledgements. We are grateful to Dr. V. L. Narayanan from Drug Synthesis and Chemistry Branch, National Cancer Institute, Bethesda, MD, USA, for in vitro evaluation of anticancer activity.

\section{Р. Б. Лесик, Б. С. Зіменковський, Д. В. Камінський, \\ А. П. Крищичии, Д. Я. Гаврилюк, Д. В. Атаманюк, \\ I. Ю. Субтельна, Д. В. Хилюк}

Тіазолідинони як лейтмотив у створенні протиракових лікарських засобів. Досвід наукової групи

3 медичної хімії ЛНМУ імені Данила Галицького

Резюме

Метою роботи був аналіз результатів дослідження протипухлинної активності 4-азолідонів і споріднених гетероциклічних сполук та формування деяких напрямків раціонального дизайну потенційних протипухлинних агентів. Синтетичні дослідження, проведені у ЛНМУ імені Данила Галицького, дозволили запропонувати низку нових спрямувань молекулярного дизайну біологічно активних 4-тіазолідинонів та споріднених гетероциклічних систем, а також одержати сфокусовану бібліотеку, яка нараховує понад 5000 нових сполук. На цей час здійснено in vitro скринінг протипухлинної активності понад 1000 сполук (US NCI протокол Developmental Therapeutic Program), 3-noміж яких 167 ідентифіковано як такі, шуо мають високу протиракову активність. Для оптимізачї і раціонального дизайну високоактивних молекул з оптимальними «лікоподібними» характеристиками та визначення можливого механізму біологічної дії проведено SAR- i QSAR-аналіз і молекулярний докінг. Кінцевою метою проекту є створення інноваційного синтетичного лікарського препарату з оригінальним механізмом діі та достатнім фармакологічним і токсикологічним профілем.

Ключові слова: синтез, 4-тіа(іміда)золідинони, тіопірано[2, 3-d]тіазоли, протипухлинна активність, (Q)SAR.

Р. Б. Лесык, Б. С. Зименковский, Д. В. Каминский,

А. П. Крищишин, Д. Я. Гаврилюк, Д. В. Атаманюк,

И. Ю. Субтельная, Д. В. Хилюк

Тиазолидиноны как лейтмотив в создании

противоопухолевых лекарственных средств. Опыт научной группы медицинской химии ЛНМУ имени Данила Галицкого

Резюме

Цель работы состояла в анализе результатов исследования противоопухолевой активности 4-азолидонов и родственных гетероциклических систем и формировании некоторых направлений рационального дизайна потенциалных противоопухолевых агентов. Синтетические исследования, проведенные $в$ ЛНМУ имени Данила Галиикого, позволили предложить ряд новых направлений молекулярного дизайна биологически активных 4-тиазолидинонов и родственных гетерочиклических сис- 
тем, а также получить сфокусированную библиотеку, насчитывающую более 5000 новых соединений. На данный момент осуществлен іn vitro скрининг противоопухолевой активности (US NCI протокол Developmental Therapeutic Program) более 1000 соединений, позволивиий идентифииировать 167 соединений с высоким противораковым эффектом. Для оптимизации и рационального дизайна высокоактивных молекул с оптимальными «drug-like» характеристиками и установления вероятного механизма биологического действия проведен $S A R-u$ QSAR-анализ и молекулярный докинг. Конечная цель проекта создание инновацинного синтетического лекарственного сресдтва с оригинальным механизмом действия, до статочным фармакологическим и токсикологическим профилем.

Ключевые слова: синтез, 4-тиа(имида)золидиноны, тиопирано [2,3-d] тиазоль, противоопухолевая активность, (Q)SAR..

\section{REFERENCES}

1. Lesyk R. B., Zimenkovsky B. S. 4-Thiazolidones: centenarian history, current status and perspectives for modern organic and medicinal chemistry // Curr. Org. Chem.-2004.-8, N 16.P. 1547-1577.

2. Prabhakar Y. S., Solomon V. R., Gupta M. K., Katti S. B. QSAR studies on thiazolidines: a biologically privileged scaffold // Top. Heterocycl. Chem.-2006.-4.-P. 161-249.

3. Tomasic T., Masic L. P. Rhodanine as a privileged scaffold in drug discovery // Curr. Med. Chem.-2009.-16, N 13.-P. 1596-1629.

4. Reginato M. J., Bailey S. T., Krakow S. L., Minami C., Ishii S., Tanaka H., Lazar M. A. A potent antidiabetic thiazolidinedione with unique peroxisome proliferator-activated receptor gammaactivating properties // J. Biol. Chem.-1998.-273, N 49.P. 32679-32684.

5. Kador P. F., Kinoshita J. H., Sharpless N. E. Aldose reductase inhibitors: a potential new class of agents for the pharmacological control of certain diabetic complications // J. Med. Chem.-1985.-28, N 7.-P. 841-849.

6. Charlier C., Mishaux $C$. Dual inhibition of cyclooxygenase-2 (COX-2) and 5-lipoxygenase (5-LOX) as a new strategy to provide safer non-steroidal anti-inflammatory drugs // Eur. J. Med. Chem.-2003.-38, N 7-8.-P. 645-659.

7. The Merck Index / Eds M. J. O'Neil et al.: $13^{\text {th }}$ ed.-New Jersey, 2001.-1818 p.

8. Sim M. M., Ng S. B., Buss A. D., Crasta S. C., Goh K. L., Lee S. $K$. Benzylidene rhodanines as novel inhibitors of UDP-N-acetylmuramate/L-alanine ligase // Bioorg. Med. Chem. Lett.2002.-12, N 4.-P. 697-699.

9. Theocharisa S., Margeli A., Kouraklis G. Peroxisome proliferator activated receptor-gamma ligands as potent antineoplastic agents // Curr. Med. Chem. Anticancer Agents.-2003.-3, N 3.P. 239-251.

10. Murphy G. J., Holder J. C. PPAR-gamma agonists: therapeutic role in diabetes, inflammation and cancer // Trends Pharmacol. Sci.-2000.-21, N 12.-P. 469-474.

11. Degterev A., Lugovskoy A., Cardone M., Mulley B., Wagner G., Mitchison T., Yuan J. Identification of small-molecule inhibitors of interaction between the BH3 domain and Bcl-xL // Nat. Cell Biol.-2001.-3, N 2.-P. 173-182.

12. Carter P. H., Scherle P. A., Muckelbauer J. K., Voss M. E., Liu R.-Q., Thompson L. A., Tebben A. J., Solomon K. A., Lo Y. C., Li Z., Strzemienski P., Yang G., Falahatpisheh N., Xu M., Wu Z., Farrow N. A., Ramnarayan K., Wang J., Rideout D., Yalamoori
V., Domaille P., Underwood D. J., Trzaskos J. M., Friedman S. M., Newton R. C., Decicco C. P. Photochemically enhanced binding of small molecules to the tumor necrosis factor receptor-1 inhibits the binding of TNF-alpha // Proc. Natl Acad. Sci. USA.-2001.-98, N 21.-P. 11879-11884.

13. Zheng W., Degterev A., Hsu E., Yuan J., Yuan C. Structure-activity relationship study of a novel necroptosis inhibitor, necrostatin-7 // Bioorg. Med. Chem. Lett.-2008.-18, N 18.- P. $4932-$ 4935.

14. Dayam R., Aiello F., Deng J., Wu Y., Garofalo A., Chen X., Neamati $N$. Discovery of small molecule integrin $\alpha_{1} \beta_{3}$ antagonists as novel anticancer agents / // J. Med. Chem.-2006.-49, N 15.- P. 4526-4534.

15. Cutshall N. S., O'Day C., Prezhdo M. Rhodanine derivatives as inhibitors of JSP-1 // Bioorg. Med. Chem. Lett.-2005.-15, N 14.-P. 3374-3379.

16. Xia Z., Knaak C., Ma J., Beharry Z. M., McInnes C., Wang W., Kraft A. S., Smith C. D. Synthesis and evaluation of novel inhibitors of Pim-1 and Pim-2 protein kinases // J. Med. Chem.2009.-52, N 1.-P. 74-86.

17. Ottana R., Maccari R., Barreca M. L., Bruno G., Rotondo A., Rossi A., Chiricosta G., Di Paola R., Sautebin L., Cuzzocrea S., Vigorita M. G. 5-Arylidene-2-imino-4-thiazolidinones: design and synthesis of novel anti-inflammatory agents // Bioorg. Med. Chem.-2005.-13, N 13.-P. 4243-4252.

18. Lesyk R., Zimenkovsky B., Kaminskyy D., Holota S., Atamanyuk D., Havryluk D., Nektegayev I., Kazmirchuk G., Subtel'na I., Roman O., Kryshchyshyn A., Khyluk D. Anticancer potential of 4-azolidones and related heterocycles // Annal. UMCS. Sectio DDD.-2006.-19, N 1.-P. 107-110.

19. Lesyk R., Vladzimirska O., Zimenkovsky B., Horishny V., Nektegayev I., Solyanyk V., Vovk O. New thiazolidones-4 with pyrazolone-5 substituent as the potential NSAIDs // Bol. Chim. Farm.-1998.-137, N 6.-P. 210-217.

20. Lesyk R. B., Artemenko A. G., Zimenkovsky B. S., Kuz'min V. E., Nektegayev I. O., Roman O. M., Atamanyuk D. V. Pharmacological screening and 2D-QSAR analysis of anti-inflammatory activity of 4-thiazolidone derivatives // Farmacevtychnyj Zhur.2003.-N 3.-P. 58-61.

21.Lesyk R., Zimenkovsky B., Subtelna I., Nektegayev I., Kazmirchuk $G$. Synthesis and antinflammatory activity of some 2-arylamino-2-thiazoline-4-ones // Acta Pol. Pharm.-2003.-60, N 6.P. 457-466.

22. Lesyk R., Zimenkovsky B., Kutsyk R. V., Atamanyuk D. V., Semenciv G. M. Synthesis and studing of antimicrobial activity of azolidine derivatives with 2-(2-chlorobenzyloxy)-5-nitrophenyl fragment in molecules // Farmacevtychnyj Zhur.-2003.N 2.-P. 52-56.

23. Zimenkovskii B. S., Kutsyk R. V., Lesyk R. B., Matyichuk V. S., Obushak N. D., Klyufinska T. I. Synthesis and antimicrobial ac- tivity of 2,4-dioxothiazolidine-5-acetic acid amides // Pharm. Chem. J.-2006.-40, N 6.-P. 303-306.

24. Nektegayev I., Lesyk R. 3-Oxyarylthiazolidones-4 and their choleretic activity // Sci. Pharm.-1999.-67.-P. 227-230.

25. Lukyanchuk V. D., Zimenkovsky B. S., Lesyk R. B., Nemyatykh $O$. D., Nektegayev I. O. Antioxidant activity of 5-arylidene-2,4thazolidinedione-3-alkanoic acid derivatives // J. Pharm. Pharmacol.-2002.-54, Suppl.-S. 1.

26. Boyd M. R., Paull K. D. Some practical considerations and applications of the national cancer institute in vitro anticancer drug discovery screen // Drug Dev. Res.-1995.-34, N 2.P. 91-109.

27. Alley M. C., Scudiero D. A., Monks A., Hursey M. L., Czerwinski M. J., Fine D. L., Abbott B. J., Mayo J. G., Shoemaker R. H., 
Boyd M. R. Feasibility of drug screening with panels of human tumor cell lines using a microculture tetrazolium assay // Cancer Res.-1988.-48, N 3.-P. 589-601.

28. Monks A., Scudiero D., Skehan P., Shoemaker R., Paull K., Vistica D., Hose C., Langley J., Cronise P., Vaigro-Wolff A., GrayGoodrich M., Campbell H., Mayo J., Boyd M. Feasibility of a high-flux anticancer drug screen using a diverse panel of cultured human tumor cell lines // J. Natl Cancer. Inst.-1991.-83, N 11.-P. 757-766.

29. Boyd M. R. Anticancer drug development guide: preclinical screening, clinical trials, and approval // Cancer drug discovery and development / Ed. A. Teicher.-New Jersey: Humana press, 1997.-Ch. 2.-P. 23-43.

30. Shoemaker $R$. $H$. The NCI60 human tumour cell line anticancer drug screen // Nat. Rev. Cancer.-2006.-6, N 10.-P. 813-823.

31. Lesyk R., Zimenkovsky B., Atamanyuk D., Jensen F., Kiec-Kononowicz $K$., Gzella A. Anticancer thiopyrano[2,3-d][1,3]thiazol-2-ones with norbornane moiety. Synthesis, cytotoxicity, physico-chemical properties, and computational studies // Bioorg. Med. Chem.-2006.-14, N 15.-P. 5230-5240.

32. Lesyk R., Vladzimirska O., Holota S., Zaprutko L., Gzella A. New 5-substituted thiazolo[3,2-b][1,2,4]triazol-6-ones: synthesis and anticancer evaluation // Eur. J. Med. Chem.-2007.-42, N 5.-P. 641-648.

33. Atamanyuk D., Zimenkovsky B., Lesyk R. Synthesis and anticancer activity of novel thiopyrano[2,3-d]thiazole-based compounds containing norbornane moiety // J. Sulf. Chem.-2008.29, N 2.-P. 151-162.

34. Matiychuk V. S., Lesyk R. B., Obushak M. D., Gzella A., Atamanyuk D. V., Ostapiuk Y. V., Kryshchyshyn A. P. A new dominoKnoevenagel-hetero-Diels-Alder reaction // Tetrahedron Lett.2008.-49, N 31.-P. 4648-4651.

35. Havrylyuk D., Zimenkovsky B., Vasylenko O., Zaprutko L., Gzella A., Lesyk R. Synthesis of novel thiazolone-based compounds containing pyrazoline moiety and evaluation of their anticancer activity // Eur. J. Med. Chem.-2009.-44, N 4.-P. 13961404.

36. Kaminskyy D., Zimenkovsky B., Lesyk R. Synthesis and in vitro anticancer activity of 2,4-azolidinedione-acetic acids derivatives // Eur. J. Med. Chem.-2009.-44, N 9.-P. 3627-3636.

37. Mosula L., Zimenkovsky B., Havrylyuk D., Missir A.-V., Chirita I. C., Lesyk R. Synthesis and antitumor activity of novel 2-thioxo-4-thiazolidinones with benzothiazole moieties // Farmacia.- 2009.- 57, N 3.-P. 321-330.

38. Havrylyuk D., Zimenkovsky B., Lesyk R. Synthesis and anticancer activity of novel nonfused bicyclic thiazolidinone derivatives // Phosphorus, Sulfur, and Silicon and the Related Elements.-2009.- 184, N 3.-P. 638-650.

39. Subtel'na I., Atamanyuk D., Szymanska E., Kiec-Kononowicz K., Zimenkovsky B., Vasylenko O., Gzella A., Lesyk R. Synthesis of 5-arylidene-2-amino-4-azolones and evaluation of their anti- cancer activity // Bioorg. Med. Chem.-2010.-18, N 14.P. 5090-5102.

40. Havrylyuk D., Mosula L., Zimenkovsky B., Vasylenko O., Gzella $A$., Lesyk $R$. Synthesis and anticancer activity evaluation of 4thiazolidinones containing benzothiazole moiety // Eur. J. Med. Chem.-2010.-45, N 11.-P. 5012-5021.

41. Solomon V. R., Hu C., Lee H. Hybrid pharmacophore design and synthesis of isatin-benzothiazole analogs for their anti-breast can- cer activity // Bioorg. Med. Chem.-2009.-17, N 21.-P. 7585- 7592 .

42. Kaminskyy D. V., Lesyk R. B. Structure-anticancer activity relationships among 4-azolidinone-3-carboxylic acids derivatives // Biopolym. Cell.-2010.-26, N 2.-P. 136-145.

43. Kaminskyy D. V., Lesyk R. B. Synthesis and biological activity of 4-thiazolidinone-3-acetic acids derivatives // Farmacevtychnyj Zhur.-2008.-N 3.-P. 70-78.

44. Kaminskyy D. V., Roman O. M., Atamanyuk D. V., Lesyk R. B. 5-Ylidene-2-thioxo-4-thiazolidinone-3-succinic acids and their derivatives: synthesis, anticancer activity, QSAR-analysis // J. Org. Pharm. Chem.--2006.-4, N 1 (13).-P. 41-48.

45. Kryshchyshyn A. P., Zimenkovsky B. S., Zaprutko L., Lesyk R. B. Synthesis and antitumor activity evaluation of 3,5a,6,11b-tetrahydro-2H,5H-chromeno[4',3':4,5] thiopyrano[2,3-d]thiazole derivatives // J. Org. Pharm. Chem.-2010.-8, N 1 (29).-P. 37-43.

46. Kryshchyshyn A., Zimenkovsky B., Lesyk R. Synthesis and anticancer activity in vitro of isothiochromeno[3,4-d]thiazole derivatives // Annal. UMCS. Sectio DDD.-2008.-21, N 1.P. $247-251$.

47. Zaharevitz D. W., Holbeck S. L., Bowerman C., Svetlik P. A. COMPARE: a web accessible tool for investigating mechanisms of cell growth inhibition // J. Mol. Graph. Model.-2002.20, N 4.-P. 297-303.

48. Paull K. D., Shoemaker R. H., Hodes L., Monks A., Scudiero D. A., Rubinstein L., Plowman J., Boyd M. R. Display and analysis of patterns of differential activity of drugs against human tumor cell lines: development of mean graph and COMPARE algorithm // J. Natl Cancer Inst.-1989.-81, N 14.-P. 1088-1092.

49. Brier S., Lemaire D., Debonis S., Forest E., Kozielski F. Identification of the protein binding region of S-trityl-L-cysteine, a new potent inhibitor of the mitotic kinesin Eg5 // Biochemistry.-2004.-43, N 41.-P. 13072-13082.

UDC 615.012.1.076:547.789.1

Received 10.01.11 